\title{
The sensitivity of investment to cash flow impact of the investment opportunities in companies listed in Tehran Stock Exchange
}

\author{
Khalil Abbasi MusLoo ${ }^{1, *}$, Mohammad Hossein PARHOON ${ }^{2}$ \\ ${ }^{1}$ Faculty Member of Management, Islamic Azad University, Firuz Abad Branch, Firuz \\ Abad, Iran \\ ${ }^{2}$ Management Group, Islamic Azad University, Firuz Abad Branch, Firuz Abad, Iran \\ *kh.abbasimo@gmail.com
}

\begin{abstract}
This study investigates the effect of investment opportunities and investment sensitivity to cash flows in co-pays listed in the Tehran Stock Exchange. Previous research in this area shows that investment opportunities, and affects the sensitivity of investment to cash flows. Tehran 1393-1389V in the time domain using the software brings new 3 were extracted. The results of the research showed that investment opportunities and cash flows of the sensitivity of investment firms listed in the Tehran Stock Exchange is a significant and positive impact on cash flows and, secondly, the sensitivity of investment in companies with higher investment, less than firms with lower investment opportunities.
\end{abstract}

Keywords: Sensitivity of investment, investment opportunities, cash flows, company size, financing

\section{Introduction}

Investment can be fundamental to the country's economy. There is no doubt that one of the first steps in the development process will increase production, increase investment would be required. For this reason, the theories in economics that cause underdevelopment of some countries to a lack of capital and investment is considered a (Nakhjavani, 1382) [1]. On the other hand, the effect of the contrast between investment and financing decisions co-financing is an important issue in literature. Choose how to finance the investment decisions because of tax issues, representation expenses, costs or affect equity and information asymmetry. Company to exploit investment opportunities are in need of cash. Cash can be made of financial resources, both domestic and foreign financial resources provided. In perfect markets (markets no agency problems and information asymmetry), the choice of financing options has no impact on investment decisions and firm value (Modigliani and Miller, 1958) [2]. In perfect markets, investment and financing decisions independent of each other. In other words, companies can always at a cost of external finance their capital expenditure to do. But if there is no market failure, is unrealistic. In the case of capital market imperfections, internal and external sources of funds cannot fully replace each other. When access to external financing is difficult, companies from 
their operating cash flow for their investment. As a result, investors are sensitive to operating cash flow.

Moreover, with the separation of ownership from management and the development of problem representation, investment, free cash flow positive relationship between investment and cash flows have been created (Dgrys and Jung, 2006) [3]. One of the major internal resources, operational cash flow. There is a direct correlation between investment and operating cash flow. According to Fazzari et al. (1988) [4] an indication of the sensitivity of investment to cash flow was introduced. Sensitivity investment cash flow reflects the company's reliance on internal resources. Accordingly, the higher the sensitivity of the investment company's cash flow, the Company is its reliance on domestic resources will be more and more financial constraints (Garcia and Svgvrb- Mara, 2014) [5]. Cash because it proves the power of public procurement, economic Drmbadlat can easily to different organizations or individuals to meet their specific needs and assist in the acquisition of goods and services (Rabii and Alipur, 1392) [6]. In another study by Mariano et al (2014) [7] was carried out, indicated that the creditors of the benefits of growth opportunities as a source of future cash flows to meet debt obligations examined the relationship between firms. Because, operating cash flow within the company's main source of financing and due to the increased investment opportunities, internal financing and external financing increases Tips differences, with the assumption of constant unforeseen operating cash flow, revision of prices stock companies with more investment opportunities, investment opportunities will be less than companies (Babajani et al., 1390: 196) [8]. Kim (2014) [9] showed a negative relationship between external financing and investment cash-flow sensitivity there. His findings also show that companies with positive net external financing investment cash flow sensitivity is less. In addition, Müller et al (2016) [10], stated that firms recognize the financial limits and evaluation of investment opportunities for them shows that firms with financial constraints highest sensitivity of investment to their cash flow.

\section{Sensitivity of investment to cash flows}

Corporate managers to maximize the value of the company, are looking for investment projects with high profitability. Projects profitable, requires appropriate financing and cheap. Various methods of financing, including domestic financing, external financing, or a combination of the two methods. But because of the agency and information asymmetry and consequently more expensive financing from abroad, companies are more inclined to use resources within the company. A company that is more and more difficult access to external sources of capital market, the company's reliance on internal resources of the company is determined by the sensitivity of investment to cash flow (Garcia and SvgvrbMara, 2014) [5]. Since the cash flows to investors and creditors cash flows depend unit profit, units of profit on invested cash resources, in addition to earning extra cash, investors are looking for returns. The process of theoretical concepts of financial reporting, financial 
flexibility is called. Financial flexibility namely, the ability of business, based on effective measures to change the amount and timing of cash flows, so that the entity can react to unexpected events and opportunities. It is obvious that the majority of the entity's financial flexibility, the ability to be more responsive to unexpected opportunities. Financial flexibility is usually in the field of financial decisions. On theoretical grounds, such as the decisions related to cash management, savings, profit distribution, financing, investment and financial decisions as they could be expressed Examples of such (Hassani, 1392: 60) [13].

The effect of the contrast between investment and financing decisions co-financing is an important issue in literature. Choose how to finance the investment decisions because of tax issues, representation expenses, publication fees and stock information asymmetry influential. Companies to take advantage of investment opportunities are in need of cash. Cash can be made of financial resources, both domestic and foreign financial resources provided. In perfect markets (markets no agency problems and information asymmetry), the choice of financing options has no impact on investment decisions and firm value (Modigliani and Miller, 1958) [2]. In perfect markets, investment and financing decisions independent of each other. In other words, companies can always at a cost of external finance their capital expenditure to do. But if there is no market failure, is unrealistic. In the case of capital market imperfections, internal and external sources of funds cannot be fully replace each other. When access to external financing is difficult, companies from their operating cash flow for their investment. As a result, investors are sensitive to operating cash flow. Most of the research on information asymmetry and capital market imperfections have shown that external financing market imperfections may be more expensive than domestic financing. Recent research has shown that information asymmetry is due to the higher cost of capital (Easley and Hara, 2004) [15]. The company access to external resources in the capital market is more difficult, more of the needed financial resources from domestic sources, the company provides. Such companies as "company suffered financial constraints" is called. The amount a firm reliance on domestic sources through "sensitivity of investment - cash flow," the company is determined (hardware designs et al., 1988) [4].

In other words, the sensitivity of cash flows - investors, the reaction of investors is the cash flow generated by the Company (Carpenter and Petersen, 2002) [16]. Through regression coefficient of sensitivity provided by investment cash flow by controlling the growth opportunities by Tobin's Q, measured (hardware designs et al., 1988) [4]. Minex et al (1988) [4], said that companies that have low dividend, more sensitive to fluctuations in cash flow than firms with higher dividend income, are. Also Mkyna and Ajygvvyl (2016) [17], as stated, companies with lower dividend payout ratio of cash flow are more sensitive to fluctuations. With constant investment opportunities, reduction in internal funds, reducing capital expenditures encounter companies with cost information will follow. Companies with financial constraints to investment decisions effectively access and the 
level of internal resources, without limitation sensitive financial companies (Basti N., 2016) [18]. So, between cash flow and investment in companies with financial constraints

\subsection{History Research}

\subsubsection{Internal research}

Hosseinpur (1384) [28], in a study entitled "The Relationship between risk factors and investment cash flow sensitivity of firms listed in the Tehran Stock Exchange" with 87 companies over a period of five years (1379 to 1383), the examine the relationship between size, value added, the percentage of dividend payment background of the company and the sensitivity of investment to cash flows. The results showed that the size, value, dividend payout ratio and sensitivity of investment firms - Cash flow positive relationship exists, but the background of the company and the sensitivity of investment cash flow connection exists. Kashanipoor et al (1389) [29], in a study entitled "Financial constraints and the sensitivity of investment to cash flows in the Tehran Stock Exchange", 96 financial companies listed on the Tehran Stock Exchange during the period from 1381 to 1387 studied Contract. The results showed that companies with financial constraints than companies without financial constraints, the higher sensitivity of investment to cash flows. Karimi et al (1389) [30], the effect of financial leverage and the opportunity to grow their companies were evaluated on investment decisions. The results showed that there is a significant negative relationship between financial leverage and investment decisions. In other words, companies with higher debt than others, invest less. The results showed there is a significant relationship between growth opportunities and investment decisions. Rbsalhy and Ashraf (1390) [31], in a study entitled "The role of determining sensitivity of investment cash reserves - Cash flow Drbvrs Tehran Stock Exchange listed companies' financial data of 72 listed companies in Tehran Stock Exchange during the period from 1378 to 1387 examined. Finding a positive role in reducing the sensitivity of investment cash reserves - the company's cash flow. Mahmoudi et al (1392) [32], in a study entitled "Review and compare investment opportunities in the short-term, medium and long term in Iran" to explore a variety of markets available for investment in Iran's during different periods of time. But, in the long run, both in terms of average return period and in terms of the performance of any of the land market and housing market is well operative units. The lowest yield and the worst performance in all phases of dollars. Pourheydari and Qasmyaqbash (1393) [19], in a study entitled "The Effect of commercial membership in the cash flow sensitivity of investment" business group membership to determine the effect of the sensitivities of investment - cash flow of 120 companies listed on Tehran Stock Exchange paid during the period from 1382 to 1390 . The results indicate that a significant relationship between cash flow and investment firms is not a member. 


\section{External research}

Shin and Park (1999) [33], the relationship between cash flow and investment corporations in Korea, did not see. While other studies in Korea and Japan a positive relationship between cash flow and investing in companies that are not members, they report indicating that the independent companies face more financial constraints on investment decisions. Moines (2002) [34], in a study entitled "The sensitivities of investment - cash flow: limited companies, the firms unlimited" examines the relationship between financial constraints and investment - cash flow to pay European companies for the period 2001-1987. The results showed that the sensitivity of investment to cash flow, to companies with financial constraints than companies without financial constraints. Shvbn and Vnhvl (2007) [35], in a study entitled "The Impact of growth opportunities on the sensitivity of investment - cash flow" by selecting a sample of 2040 Co-year period 2003-1992, the effect of growth opportunities on the sensitivity of investment to flow cash paid in Belgian companies. The results showed that increasing the sensitivity of investment to cash flows is reduced and growth opportunities. Song (2009) [36], in a study entitled "The relationship between financial leverage and investment decisions," the relationship between financial leverage and investment opportunities payment. The results showed that companies that have more growth, lower leverage ratios. Chang et al (2011) [37], in a study titled "Investment Opportunities, free cash flow and pricing of stock at the prompt issuance of debt designated" the role of investment opportunities and free cash flow, the debt's guaranteed. The results showed that the investment opportunities of an economic unit is set to announce the issuance of debt, there is a significant positive relationship. Atting et al (2013) [38], in a study entitled "The legitimacy of the company and the cash flow sensitivity -Srmayhgzary the effect of corporate social responsibility on cash flow sensitivity - Investment paid during the period from 1992 to 2010. The results showed that corporate social responsibility by reducing the information asymmetry and agency costs Srmayhgzary impact on cash flow sensitivity. This means that the sensitivity of investment to internal cash flow decreases with increasing corporate social responsibility rating. Arestani et al (2013) [39], in a study entitled "dividend policy, collection and financing investment opportunities in the industrial sector in Malaysia," the relationship between dividend policy, investment opportunities and financing of industrial companies in Malaysia they paid. The results showed that the type of financing of investment opportunities and dividend policy had a significant positive relationship. Kim (2014) [9] investigated under the effect of external financing cash holdings and cash flow of investment sensitivity can be examined. It also stated that financially constrained firms are usually high levels of cash and low levels of internal cash flow. The findings of this study indicate that both firms and companies without financial constraints limit a negative relationship between operating cash flow and financing out there. Aspalyyr and Garyjlya (2015) [40], in a study entitled "Is investment opportunities sensitivity of investment to cash flows affect?" The Belgian small and medium enterprises paid during the period 
2004-2002.

One of the most important decisions for managers make decisions regarding the financing of education projects and inflow and outflow of cash in the company, retire or development investment capital assets and investment. Several factors, including the nature of the activities, assets and economic conditions prevailing in the society can affect corporate financing and hence profitability. The results of this economic transactions with the use of analytical methods to identify an effective and dynamic, knowledge-based decisions can be provided by governments, managers and investment. Analysis of the relationship between cash flow and investment helps company managers in connection with the financing. Given that the range of users of financial statements, investors, analysts and creditors are expected this study will make a significant contribution to all segments. Research Methodology deals with the study of the nature and method of cross correlation. All companies listed on the Stock Exchange.

\subsubsection{Theories and research models}

In this part of achieving the objectives of the study and based on theoretical and research background, raised, Frzyh-Hay study has been designed and developed as follows: First hypothesis: the company's cash flow and investment opportunities and has a significant positive effect on firm investment.

$\mathrm{I}_{\mathrm{t}=} \beta_{0}+\beta_{1}$ CFLOW $_{\mathrm{t}}+\beta_{2} Q_{\mathrm{t}}+\beta_{3} L e v_{\mathrm{t}}+\beta_{4}$ Size $_{\mathrm{t}}+\varepsilon_{\mathrm{t}}$

Model 1

$\mathrm{I}_{\mathrm{t}=} \beta_{0}+\beta_{1}$ CFLOW $_{\mathrm{t}}+\beta_{2}$ Lev $_{\mathrm{t}}+\beta_{3}$ Size $_{\mathrm{t}}+\varepsilon_{\mathrm{t}}$

Model 2

\subsubsection{The definition and measurement of variables}

Independent variables

The independent variable of this research, investment opportunities and cash flow is operating.

\section{1- investment opportunities:}

Tobin's Q ratio in several studies (for example Hvakymyan and Hvakymyan [41], 2009; cloud and Gadfrd [42], 2010; and Rbsalhy and ethical, [43] in 1390), is used. In fact, to calculate Tobin's Q ratio (growth opportunities) of equation (1) is used.

To calculate the market value of assets, liabilities Total book value and market value of common stock is calculated) (Nvrvsh and Yazdani, 1388) [45]. 


\section{2- Measurement of operating cash flow:}

Operating cash flow is derived from the statement of cash flows. The dependent variable

The dependent variable, investment in fixed assets of the firms. To calculate the ratio of the change in the net amount invested in fixed assets during the period the book value of assets used in the beginning of the period. Also, the sensitivity of cash flows - Investing prepared by the regression through the index of investment cash flow measured by controlling the growth opportunities (both software and et al., 1988) [4].

\section{Research findings}

R2 adjusted for the relationship between dependent and independent variables will be used. For analyzing data mining results, Excel and Eviews software will be used.

\subsection{Descriptive statistics of variables}

Table 1. Descriptive statistics of variables for the model 162 sample companies during 5 years, representing a descriptive parameters are for each variable separately. These parameters generally include data on central parameters such as mean, median, maximum, minimum, and distribution of information on measures such as standard deviation, skewness and kurtosis is. The Central Index Average, which reflects the equilibrium point and the center of gravity is distributed and centralized index is perfect for showing off. For example, the average size of the company (5.935) these are data suggest that most of the variables have been focused on this point. The middle of one of the central indicators show the status of the community. As Table 1 shows, the median investment variables and company size respectively (0.0069) and (5/8648) These are shows that half of the data is less than this amount and half are greater than this amount. In general, scattering parameters, the criteria for determining the distribution of each other or the distribution of data compared to the mean. One of the most important scattering parameters, the standard deviation. This parameter variables growth opportunities and investment respectively (0.7739) and (0.1016) is. Elongation rate of frequency curve of the normal curve is called land or strain. If the strain is nearly zero, frequency curve in terms of strain-balanced situation will be normal. If this value is positive, highlighting curves if it is negative, wide curves. 
Table 1: Descriptive statistics of variables

\begin{tabular}{|l|c|c|c|c|c|c|}
\hline Variables & Average & Middle & the most & Least & Standard deviation & Elongation \\
\hline investment & 0.0299 & 0.0069 & 0.7466 & -0.6078 & 1.1016 & 17.6607 \\
\hline Growth opportunities & 1.9755 & 1.7655 & 6.8363 & 1.0360 & 0.7739 & 6.9624 \\
\hline Operating cash flow & 0.1254 & 0.1079 & 0.6424 & -0.3360 & 0.1365 & 3.8883 \\
\hline Financial Leverage & 0.6148 & 0.6094 & 3.0604 & 0.0657 & 0.2750 & 21.6918 \\
\hline size of the company & 5.935 & 5.8648 & $8 / 8.2238$ & 3.8651 & 0.6646 & 3.7742 \\
\hline
\end{tabular}

\subsection{The first hypothesis test results}

Therefore, the first hypothesis of the study is "the company's cash flow and investment opportunities in venture capital and has a significant positive impact." Azrabth following hypothesis is used.

$\mathrm{I}_{\mathrm{t}=} \beta_{0}+\beta_{1} \mathrm{CFLOW}_{\mathrm{t}}+\beta_{2} \mathrm{Q}_{\mathrm{t}}+\beta_{3} \operatorname{Lev}_{\mathrm{t}}+\beta_{4}$ Size $_{\mathrm{t}}+\varepsilon_{\mathrm{t}}$

To test the first hypothesis of the study and $\beta \_2 \beta \_1$ factor model is examined. If you achieved a significant level for each factor variable $\beta \_1$ and $\beta \_2$ less than $05 / 0$, and if the value of the test $(t)$ is positive, the first hypothesis was not rejected.

Table 2: The results of estimating equation (1) to test the first hypothesis

\begin{tabular}{|l|c|c|c|c|}
\hline $\mathrm{I}_{\mathrm{t}=} \beta_{0}+\beta_{1} \mathrm{CFLOW}_{\mathrm{t}}+\beta_{2} Q_{\mathrm{t}}+\beta_{3}$ Lev $_{\mathrm{t}}+\beta_{4}$ Size $_{\mathrm{t}}+\varepsilon_{\mathrm{t}}$ & \multicolumn{3}{|c|}{} \\
\hline Variable & $\begin{array}{c}\text { The estimated } \\
\text { coefficients }\end{array}$ & $\begin{array}{c}\text { standard } \\
\text { error }\end{array}$ & $\begin{array}{c}\mathrm{T}- \\
\text { statistic }\end{array}$ & $\begin{array}{c}\mathrm{P}- \\
\text { Value }\end{array}$ \\
\hline Intercept & -0.0438 & 0.0319 & -1.3725 & 0.1704 \\
\hline The company's operating cash flow i at time t & 0.0216 & 0.0099 & 2.1832 & 0.0294 \\
\hline $\begin{array}{l}\text { Growth opportunities for the company i in } \\
\text { period t }\end{array}$ & 0.0026 & 0.0023 & 2.1066 & 0.0488 \\
\hline Financial leverage the company i in period t & -0.0366 & 0.0115 & -3.1638 & 0.0016 \\
\hline Size of company i in period t & 0.0175 & 0.0053 & 3.2841 & 0.0011 \\
\hline
\end{tabular}

The results set forth in Table 2 indicate that the probability (P-Value) calculated for the variable operating cash flow (0294/0) and the estimated coefficient for positive (0216/0) is. And variable growth opportunities for the company (0488/0) and the coefficient estimates for the positive (0026/0), respectively. This suggests that investment has a positive impact on investment opportunities and cash flows; therefore, the first research hypothesis it is not ruled out. The coefficient of determination shows Model 39/55 Changes dependent variable (investment) is followed by the independent variable and control. It should be noted that the control variables, financial leverage (Lev), firm size (SIZE) has a significant impact on investment. Because the t-statistic for the variables likely financial leverage, firm size is less than $05 / 0$ error.

The results of testing the first hypothesis suggests that investment opportunities (growth opportunities) and cash flows of the investment have a positive impact. In other words, by 
increasing the cash flow within the company and increasing investment opportunities, investment in companies increases. As a result, the first hypothesis is accepted. This positive relationship between investment and cash flow sensitivity of investment to cash flow refer to the sensitivity of the reaction of the cash flow generated by the investment company. The first reason that company when cash flow is high, most investors is that the internal funds is less expensive compared to foreign funds. The second reason is that managers tend to indulge in the use of internal funds. Finally, the third reason cited is that the cash flows associated with investment opportunities. Therefore, it can be concluded that investment and cash flow are highly correlated with each other. In general, companies with high growth opportunities in order to take advantage of potential investment opportunities and avoiding the exploitation of profitable investment opportunities, to maintain a high cash flow. Thus, the relationship between investment and cash holdings, is positive. Because the companies with high investment in fixed assets, in order to make capital expenditures, will probably hold more cash. Also, as stated by increasing investment opportunities, increased investment in the company. Investment needs and requirements are essential for companies to look for growth opportunities. Growth opportunities (investment), is the driving force that motivate, reward is for investors. In fact, investors are looking to maximize their wealth. Meanwhile, investors should always consider risk in their investment decisions. Because what is successful, optimal use of available investment opportunities for this should be Rshdra fiscal policies affecting the opportunities identified in the business units. So we can conclude that with the availability of more investment opportunities, probably more likely that the company could invest more with lower risks and returns more.

The results of the first hypothesis with research findings hardware designs et al (1988); Karpntrv Peterson (1995), chlorine (1999), Hennessy (2004), Spirit (2006), A. et al (2006); Dgrys and Jung (2006); Hosseinpur (1384); Kashanipoor et al. (1389); and Rbsalhy and Majid Ashraf (1390) are consistent and contrary to the findings Karimi et al (1389) is. Because, the results indicate that a significant relationship between growth opportunities and investment decisions is not.

\subsection{The second hypothesis test results:}

Therefore, the second hypothesis is "a higher sensitivity of investment to cash flows of investment opportunities in companies with less than companies with lower investment opportunities."

$\mathrm{I}_{\mathrm{t}=} \beta_{0}+\beta_{1}$ CFLOW $_{\mathrm{t}}+\beta_{2} \operatorname{Lev}_{\mathrm{t}}+\beta_{3}$ Size $_{\mathrm{t}}+\varepsilon_{\mathrm{t}}$ 
Table 3: The results of estimating equation (2)

The third hypothesis testing in firms with high investment opportunities

\begin{tabular}{|l|c|c|c|c|}
\hline Variable & $\begin{array}{c}\text { The estimated } \\
\text { coefficients }\end{array}$ & $\begin{array}{c}\text { standard } \\
\text { error }\end{array}$ & $\begin{array}{c}\text { T- } \\
\text { statistic }\end{array}$ & $\begin{array}{c}\text { P- } \\
\text { Value }\end{array}$ \\
\hline Intercept & -0.5221 & 0.0472 & -1.1000 & 0.272 \\
\hline $\begin{array}{l}\text { The company's operating cash flow i } \\
\text { at time t }\end{array}$ & 0.0681 & 0.03138 & 2.17 & 0.0280 \\
\hline $\begin{array}{l}\text { Financial leverage the company i in } \\
\text { period t }\end{array}$ & -0.0072 & 0.0072 & -0.0311 & 0.815 \\
\hline Size of company i in period t & 0.015 & 0.0081 & 1.89 & 0.062 \\
\hline
\end{tabular}

Table 4: The results of estimating equation (2)

The third hypothesis testing in firms with low investment opportunities

\begin{tabular}{|l|c|c|c|c|}
\hline Variable & $\begin{array}{c}\text { The estimated } \\
\text { coefficients }\end{array}$ & $\begin{array}{c}\text { standard } \\
\text { error }\end{array}$ & T-statistic & P-Value \\
\hline Intercept & 0.05225 & 0.03502 & 1.49 & 0.138 \\
\hline The company's operating cash flow i at time t & 0.1009 & 0.0471 & 2.14 & 0.034 \\
\hline Financial leverage the company $\mathrm{i}$ in period t & -0.0492 & 0.01951 & -2.52 & 0.013 \\
\hline Size of company i in period t & 0.0029 & 0.0053 & 0.56 & 0.576 \\
\hline
\end{tabular}

To test the second hypothesis of this study $\beta \_1$ factor in the model is examined.

The second hypothesis into two groups for analysis of growth opportunities up and down on growth opportunities per year divided by average And so that for firms with high growth opportunities for a number of companies with low growth opportunities are considered to be zero.

Since the estimated coefficient in the case of firms with high investment opportunities $(0681 / 0)$ the estimated coefficient in the case of firms with low investment opportunities $(1009 / 0)$ is smaller, the sensitivity of investment to cash flows in companies with investment opportunities higher than firms with low investment opportunities, less. As a result, the second hypothesis is not rejected.

The results of the second hypothesis suggests that the sensitivity of investment to cash flows in firms with high investment opportunities than firms with low investment opportunities, less, therefore the second hypothesis It is not ruled out. In other words, investing in firms with low investment opportunities than firms with high investment opportunities, the cash flows are more sensitive to. This means that a stronger relationship between investment and cash flows in firms with low investment opportunities than firms with high investment opportunities there. High investment, more sensitive to increases or decreases in operating cash flow shows. Overall, operating cash flow within the company's main source of funding. Their internal resources. If so, then stock prices of these reviews 
are followed and revised in direct correlation with operating cash flow will be unpredictable. In addition, due to the fact that with increasing investment opportunities, the difference in the cost of financing increased domestic and external financing, the assumption of constant unforeseen operating cash flow, re-solicited stock prices of firms with investment opportunities, greater opportunities for companies will be less investment. In other words, it is predicted that by increasing investment opportunities, share price reaction to unforeseen operating cash flow (operating cash flow, the response factor) increases. Since profit is operating cash flow is expected to increase earnings response coefficient by increasing the investment opportunities. However, it should be noted that vendors invest their capital in companies that can profit in them are greater and better performance. . The results of the second hypothesis with research findings Shvbn and Vnhvl (2007); and Aspalyyr and Garyjlya (2015) is consistent.

\section{Conclusion}

A stronger relationship between investment and cash flows in firms with low investment opportunities than firms with high investment opportunities there. High investment, more sensitive to increases or decreases in operating cash flow shows. Thus, the relationship between investment and cash holdings, is positive. Because the companies with high investment in fixed assets, in order to make capital expenditures, will probably hold more cash. Also, as stated by increasing investment opportunities, increased investment in the company. Investment needs and requirements are essential for companies to look for growth opportunities.

\section{References}

[1] Nakhjavani, Ahmed. 1382. Iran's economy. Publishing Training Centre and Industrial Research (Iran), first edition, pp. 47-36.

[2] Modigliani, F. and Miller, M. 1958. The cost of capital, corporation finance and the theory of investment. The American Economic Review. Vol. 48, PP. 261-297.

[3] Degryse, H. and Jong, A. 2006. Investment and internal finance: asymmetric information or managerial discretion? International Journal of Industrial Organization, No. 24, PP. 125-147.

[4] Fazzary, S., Hubbard, R. G., \& Petersen, B. (1988). Financing Constraints and Corporate Investment. Brookings Papers on (2), 141-195.

[5] Garcia J.L, \& Sogorb- Mira, F. (2014). Sensitivity of external resource to cash flow under financial constrained .International Business Review.

[6] al-Rubaie, Khadija, and Alipur, Said. (1392). the effect on shareholders and provide additional cash holdings of cash in the business model determines the optimal range. Eleventh National Conference on Accounting Iran, Mashhad, Ferdowsi University of Mashhad, http://www.civilica.com/Paper-IAAC11-IAAC11_054.html

[7] Mariano,B. Josep,A.Giné,T (2014) Creditor Intervention, Investment, and Growth Opportunities DOI: 10.1007/s10693-013-0188-9 
[8] Babajani, J., Blue, Qasim; Alyzadh, Ali. (1390). The relationship between investment opportunities and value relevance of operating cash flow and accruals. Quarterly Stock Exchange, No. 13, pp. 211-191.

[9] Kim, Tae-Nyun., (2014). The impact of cash holding and external financing on investment-cash flow sensitivity. Review of accounting and finance. 13(3), 251-273.

[10] Mulier, K. Schoors, K. Merlevede,B (2016) Investment-cash flow sensitivity and financial constraints: Evidence from unquoted European SMEs. Journal of Banking \& Finance, , Volume 73, December 2016, Pages 182-197,2016

[11] Arslan, O., Florackis, C., Ozkan, A. 2006. The role of cash holdings in reducing investment-cash flow sensitivity: evidence from a financial crisis period in an emerging market. Emerging Markets Review, No. 7, PP. 320-338.

[12] Edmans, A and Jayaraman, S. (2016). The Source of Information in Prices and Investment-Price Sensitivity. Journal of Financial Economics (JFE), Forthcoming; Simon Business School Working Paper No. FR 16-01. Available at SSRN: https://ssrn.com/abstract=2715192 or http://dx.doi.org/10.2139/ssrn.2715192.

[13] Hosni, Mohammad. (1392). Experimental study of the relationship between investment cash flow sensitivity and accounting conservatism (or efficient contracting perspective distorted view of information systems?). Accounting and Auditing Reviews, Volume 20, Issue 3, pp. 84-59.

[14] Kulkarni,P Chirputkar,A.V(2014) Impact of SME Listing on Capital Structure Decisions. Procedia Economics and Finance 431 - 444

[15] Easley, D., O’Hara, M., 2004. Information and the cost of capital. Journal of Finance $59,1553-1583$.

[16] Carpenter, R.E. and B.C. Petersen (2002), 'Is the Growth of Small Firms Constrained by Internal Finance?', The Review of Economics and Statistics, Vol. 84, No. 2 (May), pp. 298-309.

[17] Makina, D. Ejigu W.L (2016) The source of investment cash flow sensitivity in manufacturing firms: is it asymmetric information or agency costs? South African Journal of Economic and Management Sciences http://dx.doi.org/10.17159/2222$\underline{3436 / 2016 / v 19 n 3 a 6}$

[18] Nadia,B (2016) Corporate Investment and Cash-Flow Sensitivity: Evidence from a Jasmin Revolution Period in Tunisian Market Asian Economic and Financial Review, 2016, vol. 6, issue 11, pages 634-646

[19] Pourheydari, hope. And Aqbash Ghasemi, Ali. 1393. The effect of commercial membership in the cash flow sensitivity of investment. Journal of financial literacy analysis papers, of Issue 23, pp. 43-29.

[20] Cleary, Sean, 1999. The relationship between firm investment and financial status. Journal of Finance 54,673-692.

[21] Hennessy, Christopher, 2004. Tobin's Q, debt overhang, and investment. Journal of Finance 59, 1717-1742.

[22] Rauh, Joshua, 2006. Investment andfinancing constraints: Evidence from the funding of corporate pension plans. Journal of Finance 61, 33-71. 
[23] Hubbard, R.G., (1998), Capital market imperfections and investment, Journal of Economic Literature, Vol. 36, pp. 193-225.

[24] Greenwald, B., Stiglitz, J.E., and Weiss, A., (1984), Informational imperfections in the capital market and macroeconomic fluctuations, American Economic Review, Vol. 74, pp. 194-199.

[25] Myers, S.C., and Majluf, N.S., (1984), corporate financing and investment decisions when firms have information that investors do not have, Journal of Financial Economics, Vol. 13, pp. 187-221.

[26] Jensen, M.C. (1986). Agency cost of free cash flow, corporate finance, and takeovers, American Economic Review, Vol. 76, pp. 323-329.

[27] Stulz, R., (1990), Managerial discretion and optimal financing policies, Journal of Financial Economics, Vol. 26, pp. 3-27.

[28] Hosseinpur, Zahra. 1384. The Relationship between risk factors and sensitivity of investment - cash flow Drbvrs securities of companies listed in Tehran. MA thesis, Faculty of Economics and Administrative Sciences, University of Isfahan.

[29] Kashanipoor, Muhammad, strong, Said; Nqynzhad, Bijan and Rasaiian, Amir. 1389. Financial constraints and the sensitivity of investment to cash flows in the Tehran Stock Exchange. The journal Advances in Accounting, University of Shiraz, Volume II, Issue II, pp. 74-51.

[30] Karimi, F, moral and Fatemeh Rezaei October. (1389). The effect of financial leverage and growth opportunities for the company's investment decisions in companies listed on the Tehran Stock Exchange, Journal of Financial Accounting, No. 8, pp. 74-6.

[31] Rbsalhy, Mehdi. And Ashraf, Majid. 1390. The role of cash reserves to determine cash flow sensitivity of investment securities of listed companies Drbvrs Tehran. Journal of Financial Accounting, Issue Issue row (9), pp. 94-75.

[32] Mahmoudi, Vahid, democracy, Muhammad, and Amamdvst, Mustafa. (1392). Review and compare investment opportunities in the timescales short, medium and long term in Iran. Journal of Research and economic policies, Year XXI, No. 65, pp. 104-83.

[33] Shin, H-H., Park, Y., 1999. Financing constraints and internal capital markets:evidence from Korean 'Chaebols'.Journal of Corporate Finance 5, 169-191.

[34] Moyen, Nathalie. (2002). Investment-Cash Flow Sensitivities: Constrained Versus Unconstrained Firms. Available at ssrn.com,id= 10599.

[35] Schoubben, F. and Van Hulle, C. 2007. The impact of growth opportunities on the investment-cash flow sensitivity. Available at ssrn.com,id=1101685.

[36] Sung, C. 2009. On the interactions of financing and investment decisions. Managerial Finance, Vol. 35, PP. 691-699.

[37] Chang, S., Chen, S. and Huang,C. 2011. Investment opportunities, free cash flow and stock valuation effects of secured debt offerings. RevQuant Finan Acc, Vol. 57, No. 3,PP. 30-35.

[38] Atting, N., Cleary, S. and Ghoul, S. 2013. Corporate legitimacy and investment-cash flow sensitivity. J Bus Ethics .DOI 10.1007/s10551-013-1693-3. 
[39] Ardestani, H. S., Rasid, S. Z. A., Basiruddin, R. and Mehri, M. 2013. Dividend payout policy, investment opportunity set and corporate financing in the industrial products sector of Malaysia. Journal of Applied Finance \& Banking, Vol. 3, No. 1, PP. 123-136.

[40] Espallier, Bert D\&Alessandra Guariglia. (2015). Does the investment opportunities bias affect the investment-cash flow sensitivities of unlisted SMEs? The European Journal of Finance Volume 21, Issue 1, 1-25.

[41] Hovakimian, A. and Hovakimian, G. 2009. Cash flow sensitivity of investment. European financial management. Vol. 15, No. 1, PP. 47-65.

[42] Abor, J. and Godfred, A. 2010. Investment opportunities, corporate finance, and dividend payout policy. Economics and Finance, Vol. 27, No. 3.

[43] Rbsalhy, M and moral, Ali. 1390. The effect of investment opportunities, financing and dividend tax policy Drbvrs accepted companies in Tehran. Quarterly Stock Exchange, No. 16.

[44] Rezaei, GH. 1392. Effects of improving the quality of financial data on the costs of representation firms listed in the Tehran Stock Exchange. Master's dissertation, University of Shiraz.

[45] Nvrvsh, Iraj; Karami, GR and VafyרSany glory. 1388. Study of Relationship between Corporate Governance and mechanisms Representation costs Pzyrfth $\neg$ Shdh companies in Tehran Stock Exchange. Accounting Research (1), SᄀS. $27-4$. 